\title{
Late Pleistocene variations of the background aeolian dust concentration in the Carpathian Basin: an estimate using decomposition of grain-size distribution curves of loess deposits
}

\author{
G. Varga ${ }^{1}$, J. Kovács ${ }^{2,3, *} \&$ G. Újvári ${ }^{4}$
}

1 Geographical Institute, Research Centre for Astronomy and Earth Sciences, Hungarian Academy of Sciences, Budaörsi út 45, H-1112 Budapest, Hungary.

2 Department of Geology, University of Pécs, Ifjúság u. 6, H-7624 Pécs, Hungary.

3 Institute of Applied Geology, BOKU, Peter Jordan Str. 70, A-1190 Vienna, Austria.

4 Geodetic and Geophysical Institute, Research Centre for Astronomy and Earth Sciences, Hungarian Academy of Sciences, Csatkai E. u. 6-8, H-9400 Sopron, Hungary.

* Corresponding author. Email: jones@gamma.ttk.pte.hu.

Manuscript received: August 2011, accepted: May 2012

\begin{abstract}
Aeolian dust deposits can be considered as one of the most important archives of past climatic changes. Alternating loess and paleosol strata display variations of the dust load in the Pleistocene atmosphere. By using the observations of recent dust storms, we are able to employ Late Pleistocene stratigraphic datasets (with accurate chronological framework) and detailed granulometric data for making conclusions on the atmospheric dust load in the past. Age-depths models, created from the absolute age data and stratigraphic interpretation, allow us to calculate sedimentation rates and dust fluxes, while grain-size specifies the dry-deposition velocity, i.e. the atmospheric residence time of mineral particles. Thus, the dust concentration can be expressed as the quotient of the dust flux and gravitational settling velocity. Recent observations helped to clarify the mechanisms behind aeolian sedimentation and the physical background of this process has nowadays been well established. Based on these two, main contrasting sedimentary modes of dust transport and deposition can be recognised: the short suspension episodes of the coarse (silt and very fine sand) fraction and the long-range transport of a fine (clay and fine silt) component. Using parametric curve fitting the basic statistical properties of these two sediment populations can be revealed for Pleistocene aeolian dust deposits, as it has been done for loess in Hungary. As we do not have adequate information on the magnitude and frequency of the Pleistocene dust storms, conclusions could only be made on the magnitude of continuous background dust load. The dust concentration can be set in the range between 1100 and $2750 \mu \mathrm{g} / \mathrm{m}^{3}$. These values are mostly higher than modern dust concentrations, even in arid regions. Another interesting proxy of past atmospheric conditions could be the visibility, being proportional to the dust concentration. According to the known empirical dust concentration - visibility equations, its value is around 6.5 to 26 kilometres.
\end{abstract}

Keywords: aeolian dust, dust concentration, grain-size, loess, Pleistocene

\section{Introduction}

The global annual input of mineral dust aerosols, lifted into the atmosphere from deflating surfaces in arid-semiarid regions, is estimated to be between 1 to 3 billion t/y (Tegen et al., 1996; Zender et al., 2003). The magnitude and frequency of these dust storm events are sensitive to environmental changes and climate owing to changing precipitation levels, wind strength, regional moisture balance, and extent of dust sources and also due to anthropogenic factors.
Dust is an active component of the climate and other environmental systems and plays important role in climate forcing. The atmospheric mineral dust particles reflect, scatter, and absorb the incoming shortwave solar and also the outgoing long wave terrestrial radiation, thereby modifying the Earth's radiation balance in a direct way (Harrison et al., 2001; Kohfeld \& Tegen, 2007; Pósfai \& Buseck 2010). However, its indirect effects are also significant. By acting as cloud condensation nuclei, these particles may alter cloud characteristics (e.g. more and smaller cloud droplets, brighter clouds) and also the 
hydrological cycle (Rosenfeld, 2001; Sassen, 2003). Due to their high Fe-content, dust particles transported to the oceans potentially play an important role in the biogeochemical cycles providing micronutrients and affecting the carbon cycle (Ridgewell, 2002; Jickells et al., 2005).

Dust particles deposited on land surfaces could accumulate in large quantities, especially during the dustier periods of the Pleistocene glacials. In certain ecological environments, the accumulated dust might form loess via diagenesis. Loess sediments cover ca $10 \%$ of continental surfaces (Pécsi, 1990), and almost the half of Carpathian Basin, where aeolian processes played gradually a more and more dominant role in the sedimentation from the Late Pliocene onwards. These widespread and thick loess-paleosol sequences record the Pleistocene glacial-interglacial variations. By correlating these sequences with ice cores and marine sequences conclusions on the timing and local/regional manifestation of global changes of environmental conditions (e.g. paleotemperature, atmospheric conditions, dust concentration) can be drawn.

A previous study on Hungarian loess (Varga, 2011) revealed that the grain-size distribution (GSD) curves of loess deposits are bimodal, with a pronounced peak in the coarse silt fraction and a shoulder in the clay-, fine silt fraction. These characteristics have been found common to our formerly analysed aeolian dust deposits in Hungary such as Lower and Middle Pleistocene loess - paleosol and Pliocene - Lower Pleistocene red clays (Kovács, 2008; Kovács et al., 2008; Varga, 2011) and also to other globally investigated terrestrial wind-blown sediments (e.g. Sun et al., 2002, 2004). The bimodal pattern of GSDs represents the mixing of two sediment populations that can be separated from each other by using mathematical methods i.e. fitting appropriate functions). These two populations can be interpreted as the fine-grained continuous background dust load of the atmosphere and the coarse-grained product of episodic dust storms, by analogy with grain-size data of recent dust observations (McTainsh et al., 1997).

In this study we made an attempt to estimate the average Pleistocene aeolian background dust concentration in the Carpathian Basin by using sedimentation rates and granulometric data from loess-paleosol sequences. These dustconcentration data might be essential for Earth climate system models in evaluating their performances in terms of dust flux reconstruction capabilities.

\section{Materials and methods}

\section{Stratigraphy and its relation to the atmospheric dust load}

Alternating loess and paleosol strata of aeolian dust deposits mirror the variations of atmospheric dust load in the Pleistocene (Fig. 1.). During the dusty cold-arid glacial periods loess formation prevailed, while in the warmer and moister interglacial/

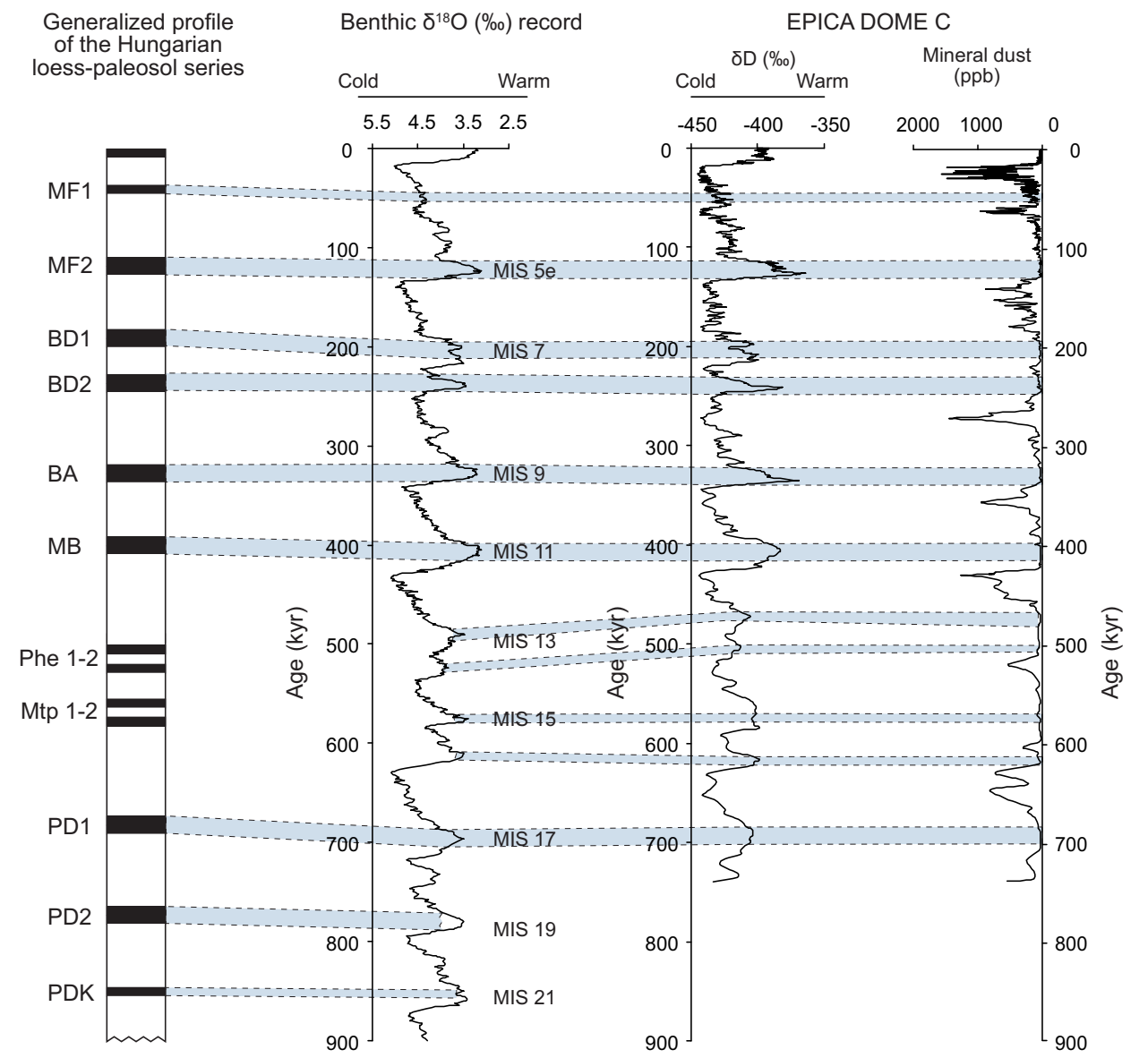

Fig. 1. Generalised loess-paleosol sequence of Hungary and its possible correlation with benthic $\delta^{18} 0$ record of deep sea sediments, and $D$ and insoluble dust in the EPICA DOME $C$ ice core. (In absence of age data, the correlations of Phe 1-2 and Mtp 1-2 weakly developed sandy and hydromorphic soils with MIS13 and MIS15 carry significant uncertainties. Sources: Pécsi \& Schweitzer, 1995; Gábris, 2007; Lisiecki \& Raymo, 2005; EPICA community members 2004). 
interstadial phases soils were formed on loess by weathering and pedogenic processes. Varga (2011) claims that there was no significant dust input during the formation of the Hungarian Middle and Upper Pleistocene paleosols, based on grain-size data.

The Upper Pleistocene loess series of Hungary include a pedocomplex that dates to the last interglacial (MF2), earlylast-glacial loess, an interstadial pedocomplex (MF1), late-lastglacial loess and the modern, Holocene soil. This stratigraphic feature fits well into the regional picture, shows similarity to the Croatian (Galović et al., 2009), Serbian (Markovic et al., 2006, 2009; Antoine et al., 2009; Stevens et al., 2011) and Austrian (Peticzka et al., 2010) sections. If any of these stratigraphic units is missing, then the series cannot be regarded as a complete sequence (Mahowald et al., 2006).

In the case of poorly dated sections, the low stratigraphic preservation potential of loess sediments, being susceptible to reworking and redeposition by hydrological processes or mass movements, is querying the use of the assumed linear aeolian sedimentation models. The origin of paleosols is another problem of loess stratigraphy; thence sometimes it is difficult to assign the initiation of paleosols in the stratigraphic column since the material from which the soils were formed are glacial loesses and the soil formation proceeded downwards in the section during interglacial periods, so the thickness of the glacial aeolian dust deposits is underestimated in most cases. This was also emphasised in a study focused on other loess-paleosol sequences in Southeastern Europe (e.g. Buggle et al., 2009). Probably, the Lower Pleistocene red paleosols reflect a largely different depositional system, and these paleosols have been formed as vertically-accreted soil direct from the wind-blown dust (Varga, 2011). For these reasons, sections with accurate chronological framework (mostly with two or more independent dating series) and almost complete stratigraphic column were used in our calculations (Table 1.).

\section{Grain-size analysis}

309 Samples from Hungarian key-sites were collected (Fig. 2.), with the focus on sections comprising Upper Pleistocene loess deposits to determine typical granulometric characteristics. The grain-size distribution of all samples was measured after chemical treatment described by Konert \& Vandenberghe, (1997). After treating the samples with $(10 \mathrm{ml}, 30 \%) \mathrm{H}_{2} \mathrm{O}_{2}$ and $(10 \mathrm{ml}$, $10 \%) \mathrm{HCl}$ to remove the organic material and the carbonate, $10 \mathrm{ml}$ of $3.6 \% \mathrm{Na}_{4} \mathrm{P}_{2} \mathrm{O}_{7} \cdot 10 \mathrm{H}_{2} \mathrm{O}$ was added to the samples in order to disperse the particles. All of the measurements were made on a Fritsch Analysette 22 Compact laser grain-size analyser, with 0.3-300 $\mu \mathrm{m}$ measurement ranges and a resolution of 62 channels.

\section{Estimation of past aeolian dust concentrations}

Crucial points in the discussion of past dust concentration are the reliable chronological framework and the sedimentary features of aeolian deposits. The age data, together with the stratigraphy determine the sedimentation rate (i.e. the amount of settled dust), while the grain-size defines the dry deposition velocity of the particles (i.e. the atmospheric residence time of the particles).

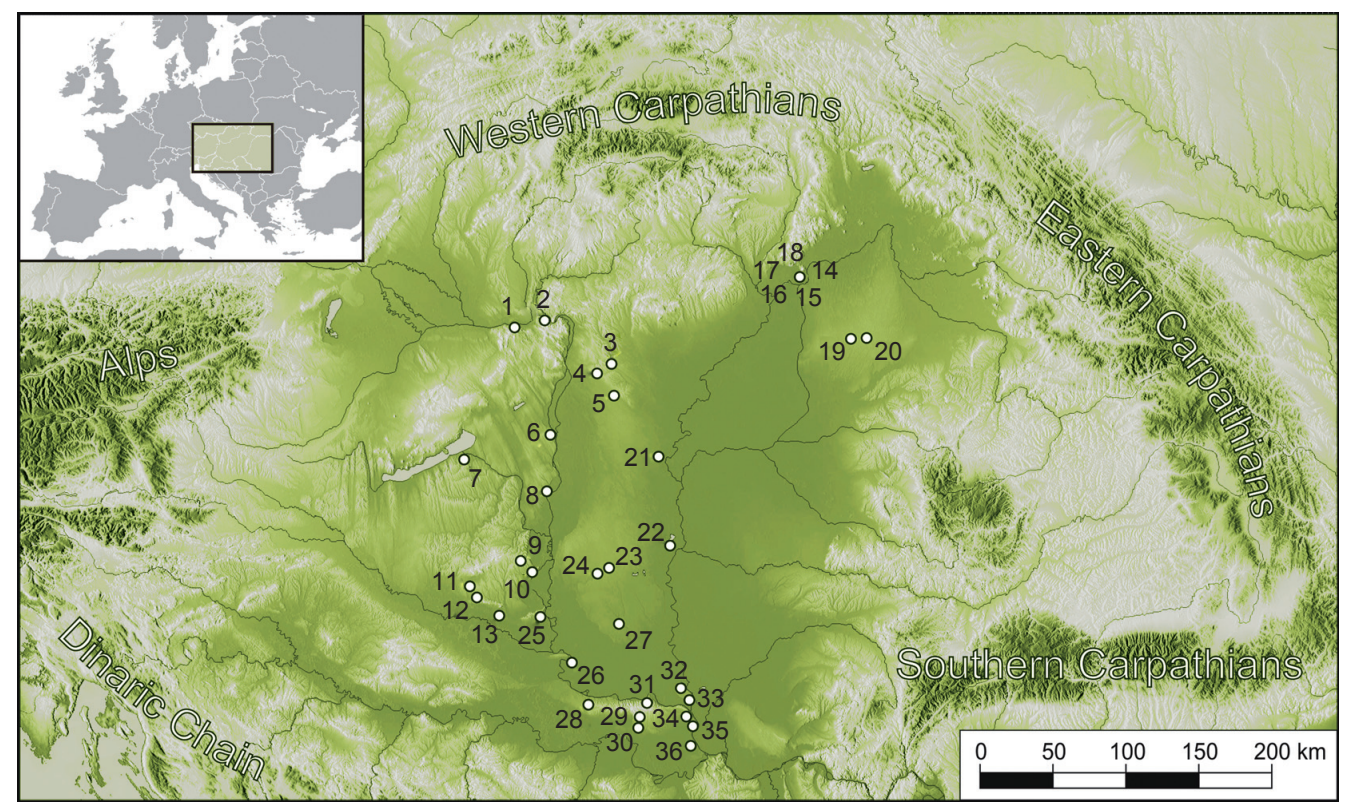

Fig. 2. Location of loess profiles considered in the paper. 1 - Süttó; 2 - Basaharc; 3 - Tápiósüly; 4 - Mende; 5 - Albertirsa; 6 - Dunaújváros; 7 - Ságvár; 8 - Paks; 9 - Üveghuta; 10 - Dunaszekcsố; 11 - Zók; 12 - Hegyszentmárton; 13 - Beremend; 14 - Bodrogkeresztúr; 15 - Csorgókút I.; 16 - Csorgókút II.; 17 - Tokaj (Patkó-quarry); 18 - Tokaj (Kereszt Hill); 19 - Látókép; 20 - Debrecen (Alföldi brickyard); 21 - Lakitelek; 22 - Szeged-öthalom; 23 - Madaras; 24 - Katymár; 25 -Zmajevac; 26 - Erdut; 27 - Crvenka; 28 - Susek; 29 - Irig; 30 - Ruma; 31 - Petrovaradin; 32 - Mošorin; 33 - Titel; 34 - Starí Slankamen; 35 - Surduk; 36 - Batajnica. (The 309 samples for the grain-size measurements were collected from Sites 2, 4, 8, 10, 11, 12, 13, 25.). 
Table 1. The list of the sites used in our calculations (source: Újvári et al., 2010).

\begin{tabular}{|c|c|c|c|c|}
\hline Country & Site name & Dating method & Stratigraphic/dating framework & Age model \\
\hline \multirow[t]{21}{*}{ Hungary } & Albertirsa & IRSL & 21 & 21 \\
\hline & Basaharc & ${ }^{14} \mathrm{C}$, TL, IRSL, AAR & $5,23,32,34,36$ & $5,32,34$ \\
\hline & Bodrogkeresztúr I & ${ }^{14} \mathrm{C}$ & $30,31,32$ & $30,31,32$ \\
\hline & Csorgókút I & ${ }^{14} \mathrm{C}$ & $30,31,32$ & $30,31,32$ \\
\hline & Csorgókút II & ${ }^{14} \mathrm{C}$ & $30,31,32$ & $30,31,32$ \\
\hline & Debrecen (Alföldi brickyard) & ${ }^{14} \mathrm{C}$ & 30,32 & 30,32 \\
\hline & Dunaszekcső & ${ }^{14} \mathrm{C}$ & 24,27 & 24,27 \\
\hline & Dunaújváros & ${ }^{14} \mathrm{C}$ & 24,27 & 24,27 \\
\hline & Katymár & ${ }^{14} \mathrm{C}$ & $9,14,30,32,34$ & $30,32,34$ \\
\hline & Lakitelek I & ${ }^{14} \mathrm{C}$ & $30,32,34$ & $30,32,34$ \\
\hline & Látókép & ${ }^{14} \mathrm{C}$ & 30,32 & 30,32 \\
\hline & Madaras & ${ }^{14} \mathrm{C}$ & $4,10,30,32,34$ & $4,10,30,32,34$ \\
\hline & Mende & ${ }^{14} \mathrm{C}$, TL, IRSL, AAR & $5,8,23,26,29,35,37$ & $5,8,26,29$ \\
\hline & Paks & TL, IRSL, AAR & $5,23,25,35$ & 5 \\
\hline & Ságvár & ${ }^{14} \mathrm{C}$ & $7,8,12,33$ & $7,8,12$ \\
\hline & Süttő & AMS ${ }^{14} \mathrm{C}$, IRSL, AAR & 22,23 & 22 \\
\hline & Szeged-Öthalom I & ${ }^{14} \mathrm{C}$ & $13,30,32$ & $13,30,32$ \\
\hline & Tápiósüly & ${ }^{14} \mathrm{C}, \mathrm{TL}$ & 8,35 & 8,35 \\
\hline & Tokaj (Kereszt Hill II) & ${ }^{14} \mathrm{C}$ & 30,32 & 30,32 \\
\hline & Tokaj (Patkó-quarry) & ${ }^{14} \mathrm{C}$ & $30,31,32$ & $30,31,32$ \\
\hline & Üveghuta-2 borehole & MS & 11,20 & 11,20 \\
\hline \multirow[t]{2}{*}{ Croatia } & Erdut & IRSL & 6 & 6 \\
\hline & Zmajevac & IRSL & 6 & 6 \\
\hline \multirow[t]{10}{*}{ Serbia } & Batajnica & MS & $3,18,19$ & $3,18,19$ \\
\hline & Crvenka & MS & 18 & 18 \\
\hline & Irig & MS, IRSL & 17,18 & 17,18 \\
\hline & Mošorin & MS & 18 & 18 \\
\hline & Petrovaradin & MS, AAR & 15 & 15 \\
\hline & Ruma & MS, AAR & 16 & 16 \\
\hline & Stari Slankamen & MS, IRSL-OSL & 18,28 & 28 \\
\hline & Surduk & AMS ${ }^{14}$ C, IRSL-OSL & 1 & 1 \\
\hline & Susek & MS & 18 & 18 \\
\hline & Titel & MS, IRSL & $1,2,18$ & 2 \\
\hline \multicolumn{5}{|c|}{$\begin{array}{l}\text { Abbreviations: }{ }^{14} \mathrm{C}=\text { conventional radiocarbon dating; } \mathrm{AMS}{ }^{14} \mathrm{C}=\text { Accelerator Mass Spectrometry radiocarbon dating; } \mathrm{TL}=\text { thermoluminescence; } \mathrm{OSL}=\text { optically } \\
\text { stimulated luminescence; } \mathrm{IRSL}=\text { infrared optically stimulated luminescence; } \mathrm{AAR}=\text { amino acid racemisation; } \mathrm{MS}=\text { magnetic susceptibility. }\end{array}$} \\
\hline \multicolumn{5}{|c|}{1 - Antoine et al. (2009); 2 - Bokhorst et al. (2009); 3 - Buggle et al. (2009); 4 - Dobosi (1967); 5 - Frechen et al. (1997); 6 - Galović et al. (2009); 7 - Gábori-Csánk (1960); } \\
\hline \multicolumn{5}{|c|}{8 - Geyh et al. (1969); 9 - Hupuczi et al. (2006); 10 - Hupuczi \& Sümegi (2010); 11 - Koloszár \& Marsi (2005); 12 - Krolopp \& Sümegi (2002); 13 - Krolopp et al. (1996); } \\
\hline \multicolumn{5}{|c|}{14 - Lócskai et al. (2006); 15 - Marković et al. (2005); 16 - Marković et al. (2006); 17 - Marković et al. (2007); 18 - Marković et al. (2008); 19 - Marković et al. (2009); } \\
\hline \multicolumn{5}{|c|}{20 - Marsi et al. (2004); 21 - Novothny et al. (2002); 22 - Novothny et al. (2009); 23 - Oches \& McCoy (1995); 24 - Pécsi \& Pevzner (1974); 25 - Pécsi (1979); 26 - Pécsi } \\
\hline \multicolumn{5}{|c|}{ et al. (1979); 27 - Pécsi (1985); 28 - Schmidt et al. (2009); 29 - Seppäla (1971); 30 - Sümegi (2005); 31 - Sümegi \& Hertelendi (1998); 32 - Sümegi et al. (2007); } \\
\hline $33-$ Vogel & 4); 34 - Willis et al. (2000); $35-\mathrm{V}$ & Packman (1988); $36-\mathrm{Z}$ & t al. (1994); 37 - Zöller \& Wagner (1990). & \\
\hline
\end{tabular}

\section{Dust flux}

The sedimentation rate is defined as:

$$
\mathrm{SR}=\mathrm{LLT} / \mathrm{DD}
$$

where LLT is the layer of loess thickness in meters and DD is the duration of deposition in years. By computing dust fluxes the effect of syn- and post-sedimentary compaction can be compensated for:

$$
\mathrm{DF}=\mathrm{SR} \times \rho
$$

where $\rho$ is dry bulk density, and DF represents the mass of deposited dust per unit area per unit time (in $\mathrm{g} / \mathrm{m}^{2} / \mathrm{y}$ ). Recently published age and sedimentation rate data and a dry density 
value of $=1.5 \mathrm{~g} / \mathrm{cm}^{3}$ (Újvári et al., 2010) have been employed for calculations of DF. Since only weakly developed paleosols and humic horizons intercalate loess deposits in the investigated Upper Pleistocene sections, the same $\rho=1.5 \mathrm{~g} / \mathrm{cm}^{3}$ dry bulk density has been used for the whole series.

\section{Grain-size and the proportion of background dust-load}

According to recent observations, two main sedimentary modes of aeolian dust transport and deposition can be recognised (Pye, 1987, 1995): larger particles are transported by surface winds in short suspension episodes, during discontinuous dust storms, smaller grains disperse to higher levels of the atmosphere and are transported by upper level air flows far from the source area as continuous back-ground dust load. However, it is worth noting that in some cases even the larger particles can transported far away from their source areas (Stuut et al., 2009). The two main modes of dust entrainment can also be identified in the bimodal GSDs of aeolian dust deposits (Sun et al., 2002, 2004; Varga, 2011; Fig. 3).

The separation of these sediment populations can be made by different mathematic techniques, including parametric curve-fitting (PCF) and end-member modelling algorithms (EMMA - Weltje, 1997; Weltje \& Prins, 2003; Vriend \& Prins, 2005). We believe that the differences (Weltje \& Prins 2007) between these two methods arise from their different approach and scope. Whereas EMMA is based on the simultaneous analysis of the whole sequence based on the covariance structure of the dataset, the input of the PCF is only one sample. The resulting (and generally) three EMMA endmembers of loess samples (Prins \& Vriend, 2007; Prins et al., 2007) represent the average dust GSD of three temporal aeolian sediment clusters of seasonal or other short-term intervals. In the case of loess deposits, the PCF populations are proposed to illustrate the background and the local-derived dust components for each sample. The process-related partitioning of EMMA end-members could justify the supposed differences of results of the two methods (Fig. 4.).

In this study, as it is aimed at providing information on the amount of background dust load, the PCF technique has been applied. According to this approach the bimodal GSDs can be interpreted as the sum of two overlapping Weibull functions (Sun et al., 2002, 2004). It must be emphasised here concerning the Weibull distribution that the wind speed at a given site also follows this continuous probability distribution (Lun \& Lam 2000), and it is expected that the GSDs of wind-blown sediments should reflect the transport agent. The applied distribution function has a form of:

$W_{1}+W_{2}=c_{1} \times\left(\frac{\alpha_{1}}{\beta_{1}^{\alpha_{1}}}\right) \times x^{\alpha_{1}-1} \times e^{-\left(\frac{x}{\beta_{1}}\right)^{\alpha_{1}}}+c_{2} \times\left(\frac{\alpha_{2}}{\beta_{2}^{\alpha_{2}}}\right) \times x^{\alpha_{2}-1} \times e^{-\left(\frac{x}{\beta_{2}}\right)^{\alpha_{2}}}$

where $W_{1}$ and $W_{2}$ are the two sediment populations, $\alpha_{1}$ and $\alpha_{2}$ are the shape parameters, defining the kurtosis of the curves (i.e. the sorting), $\beta_{1}$ and $\beta_{2}$ are the location parameters, defining the position of the curves (i.e. the grain-size), while $c_{1}$ and $c_{2}$ are weighting parameters. Iterative numerical methods were used to determine the location, shape and weight parameters as a least-squares problem, and to assess the appropriate goodness of fit of the measured and calculated data (Fig.5.).

\section{Dust concentration}

For Late Pleistocene dust concentration calculations only the continuous background dust component of the grain-size distribution curves were used, owing to the unknown magnitude and frequency of Pleistocene dust storm events. The relatively short duration of dust storms and short atmospheric residence
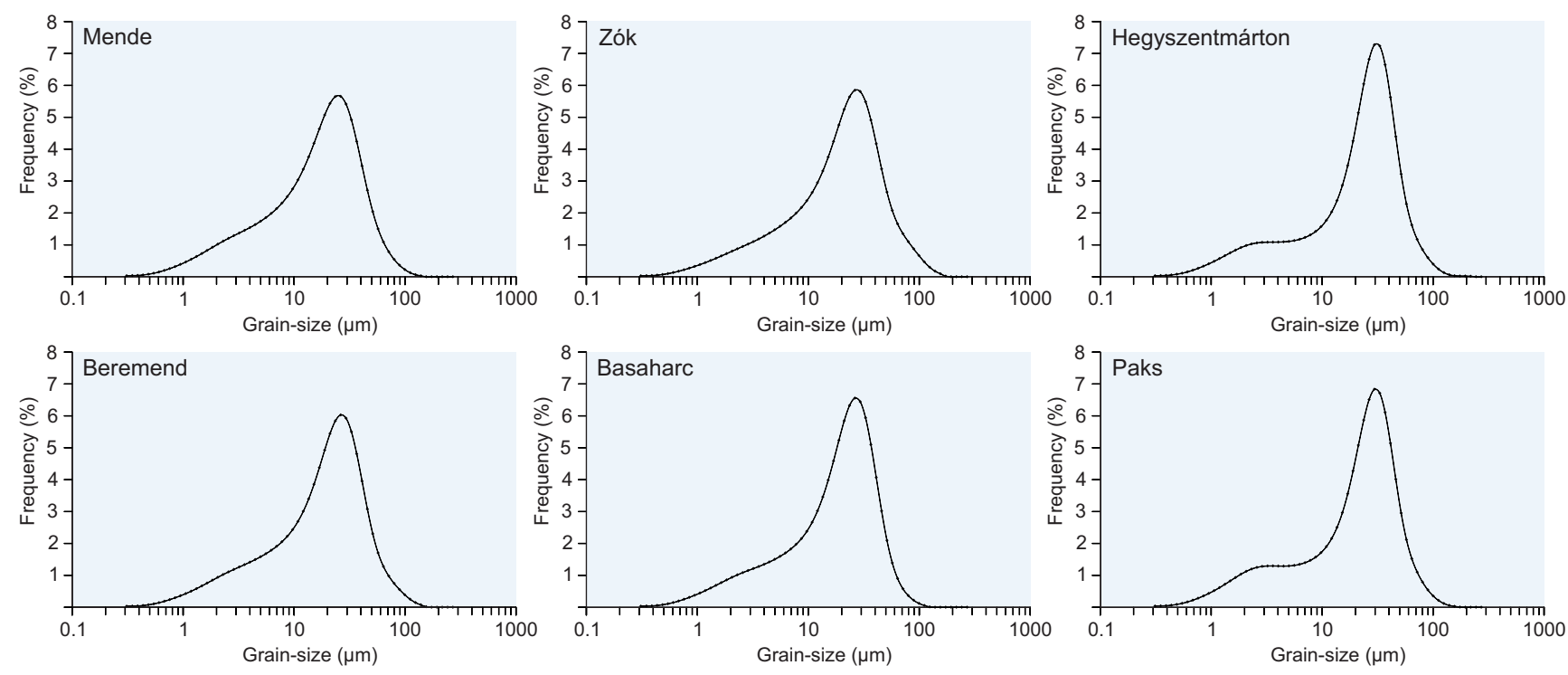

Fig. 3. Typical grain-size distribution curves of Upper Pleistocene loess samples from the Carpathian Basin. 


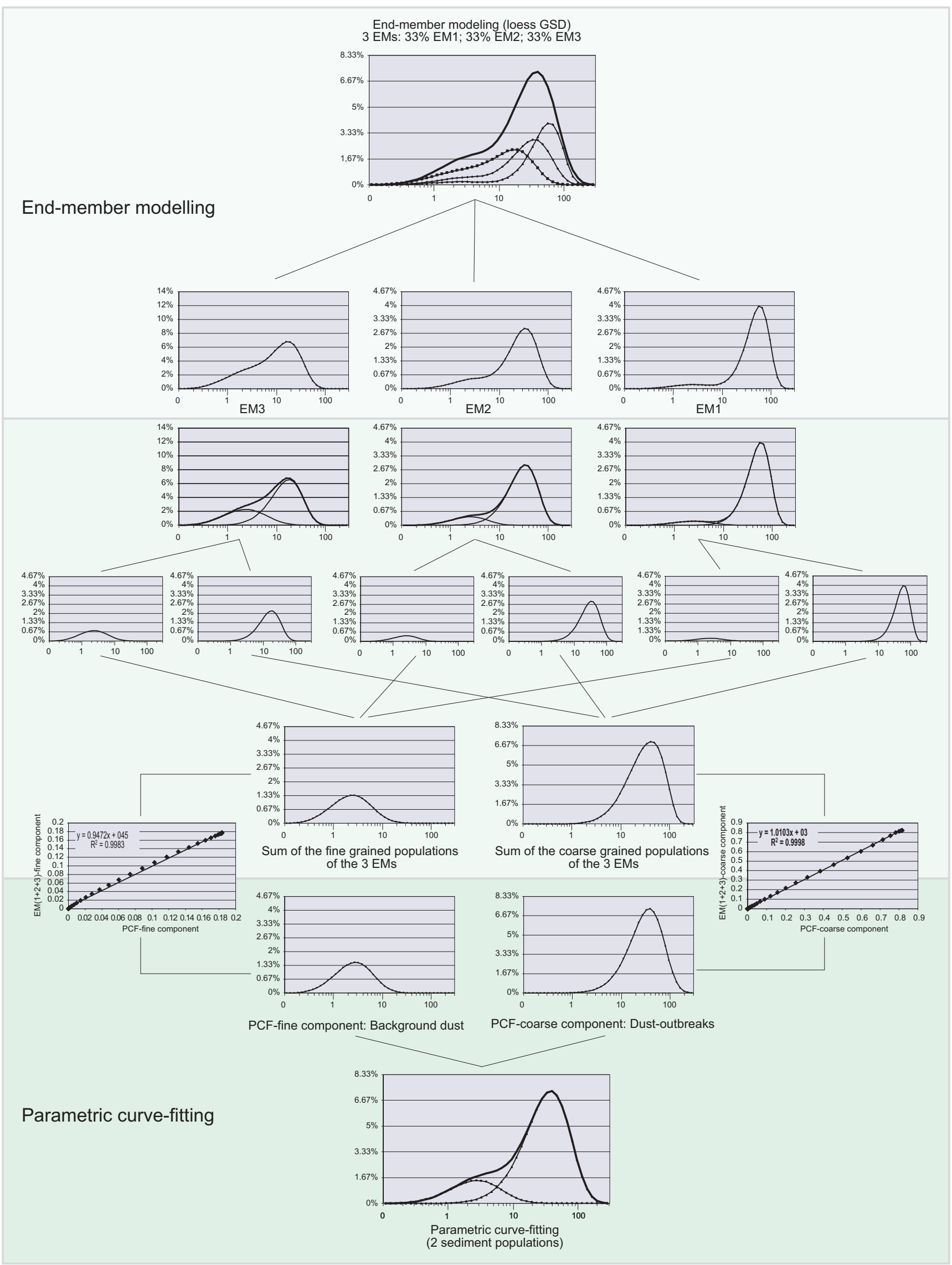

Fig. 4. Possible relationship of different mathematical methods to partitioning grain-size distribution curves: End-Member Modelling Algorithm (EMMA) and the Parametric Curve-Fitting (PCF) methods. 

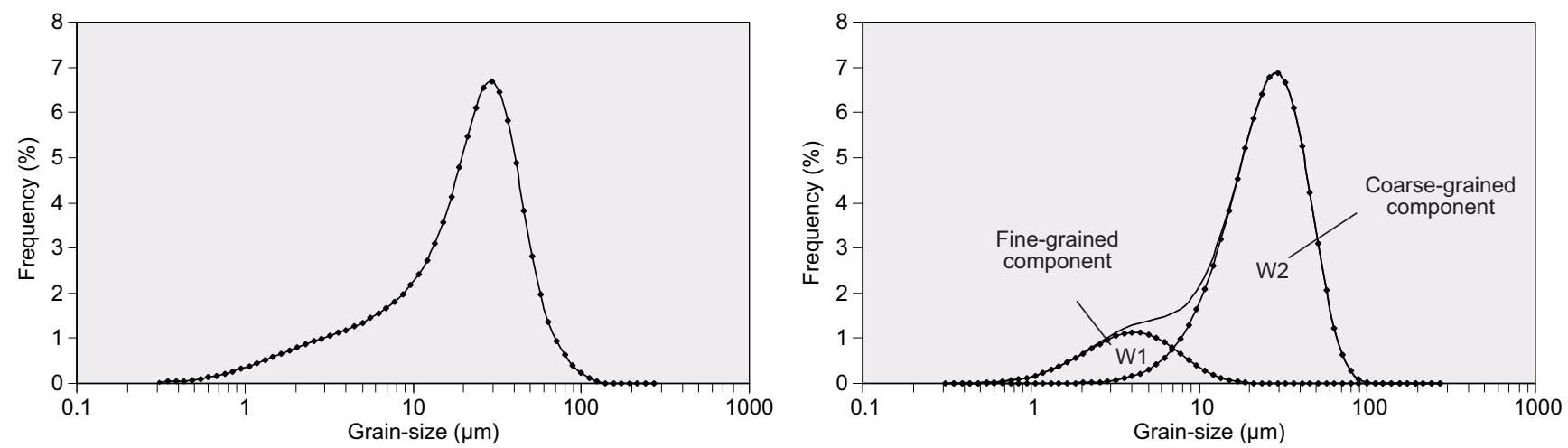

Fig. 5. Typical measured (a) and mathematically partitioned (b) grain-size distribution curves of loess samples from the Carpathian Basin.

time of storm-related coarse particles could be the source of significant uncertainties in calculations.

Dust flux represents the mass of deposited dust per unit area per unit time, so its quotient by the gravitational settling velocity $\left(\mathrm{v}_{\mathrm{s}}\right)$ will give the average atmospheric dust concentration $(\mathrm{C})$ :

$$
\mathrm{C}\left[\mu \mathrm{g} / \mathrm{m}^{3}\right]=\mathrm{DF} / \mathrm{v}_{\mathrm{S}}
$$

The gravitational settling velocity, $\mathrm{v}_{\mathrm{s}^{\prime}}$ for spherical particles larger than $1 \mu \mathrm{m}$ can be calculated approximately according to the Stokes Law as a function of the square of the grain diameter:

$$
\mathrm{v}_{\mathrm{s}}=\frac{\mathrm{d}^{2} \times \rho \times \mathrm{g}}{18 \times \eta}
$$

where $d$ is the grain diameter, $\delta$ is the particle density, $g$ is gravity, $\eta$ is the dynamic viscosity of air. The typical grain diameter of the background dust is given by:

$$
d=\frac{\sum_{i=1}^{62} x_{i} \times m_{i}}{\sum_{i=1}^{62} m_{i}}
$$

where $x_{i}$ is the measurement range of the ith channel of the laser analyser, $\mathrm{mi}$ is the mass proportion of particles related to the background dust population in the ith channel. The gravitational settling velocities for different sizes of quartz $\left(2.65 \mathrm{~g} / \mathrm{cm}^{3}\right)$ in still air are shown in Fig.6.

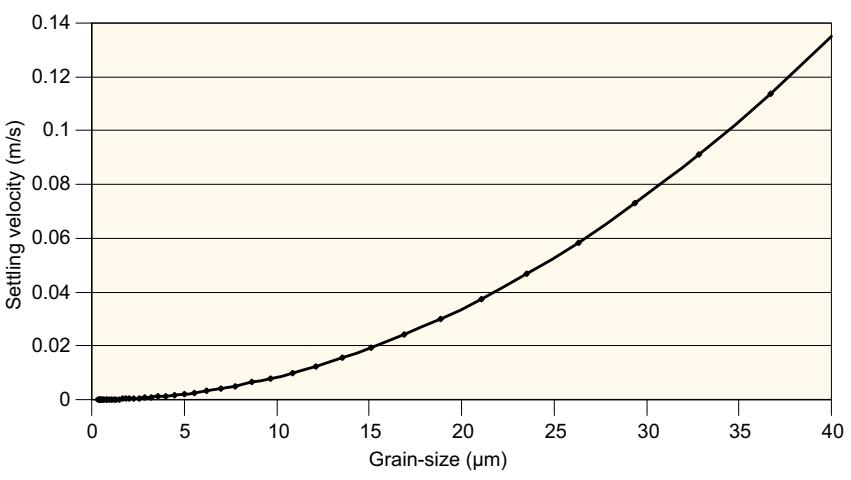

Fig. 6. Gravitational settling velocities of different sizes of quartz particles in still air.
After these calculations, the dust concentration (C) can be expressed as

$$
C=\sum_{i=1}^{62} \frac{D F \times m_{i}}{x_{i}^{2} \times \rho \times g}
$$

a function of the dust flux and the grain-size related gravitational settling velocity.

\section{Results and discussion}

The average sedimentation rate in the Carpathian Basin for the Late Pleistocene can be set in the range 0.1 to $0.95 \mathrm{~m} / \mathrm{ky}$ with a median value of $0.23 \mathrm{~m} / \mathrm{ky}$ and a mean of $0.28 \mathrm{~m} / \mathrm{ky}$ (Újvári et al., 2010). According to (Eq.2.), the dust flux values related to the above sedimentation rates are 150 to $1400 \mathrm{~g} / \mathrm{m}^{2} / \mathrm{y}$ with median and mean values of 338 and $417 \mathrm{~g} / \mathrm{m}^{2} / \mathrm{y}$, in general (the range of the first and third quartile) between 200 and $500 \mathrm{~g} / \mathrm{m}^{2} / \mathrm{y}$ (Table 2.). The $0.95 \mathrm{~m} / \mathrm{ky}$ sedimentation rate and $1400 \mathrm{~g} / \mathrm{m}^{2} / \mathrm{y}$ dust flux of the Paks site is exceptionally high, which was possibly caused by the activation of additional source areas. However, this observation needs further investigations since the GSDs were similar to granulometric characteristics of other sections.

Due to the low stratigraphic preservation potential of loess deposits, being susceptible to reworking and redeposition, reconstructed sedimentation-rate values depend on the geomorphological settings of the investigated sections. The DF values were found by Újvári et al. (2010) to be higher on loess plateaus and river terraces than on hill slopes and alluvial plains.

The bimodal grain-size distribution curves of the collected samples were mathematically partitioned into sediment populations. Statistical parameters of the separated components proved to be more useful for describing and analysing the samples than traditional statistical measures such as mean grain size, etc. The dust storm-related coarse-grained (7-71 $\mu \mathrm{m})$ sediment population has positive skewness and leptokurtic kurtosis, i.e. the material is well sorted: it represents the dust material of local source areas (e.g. alluvial plains of Danube, 
Tisza and other rivers - Buggle et al., 2008; Újvári et al., 2008). In contrast to other well-studied regions (e.g. Chinese Loess Plateau), it is difficult to draw conclusions from GSDs to sourceto-sink distances in the Carpathian Basin, due to the complex system of many local sources (Bokhorst et al., 2011).

Skewness of the fine-grained $(2.1-7.8 \mu \mathrm{m})$ component produced by the background dust load, is also positive, but the kurtosis is platykurtic, poorly sorted. The proportion of the background-dust population varied between $12.65 \%$ and $17.95 \%$, the typical grain size ranged from 4.1 to $4.4 \mu \mathrm{m}$. Further, the grain size of the fine-grained populations did not show large differences; their average GSD illustrates well the regional features of background dust load (Fig. 7).

Based on the relationship (Eq. 7) between dust concentration, dust flux and gravitational settling velocity, the calculated value of the background dust concentration can be set in the range of 1100 to $2750 \mu \mathrm{g} / \mathrm{m}^{3}$ if we count with regionally typical $200-500 \mathrm{~g} / \mathrm{m}^{2} / \mathrm{y}$ dust fluxes. Decomposition results are detailed in Table 2. Because of the usage of average GSD, a correction coefficient of $\pm 20 \%$ must be applied.

These values match and many times exceed the present-day background dust concentration values, even in arid, dusty regions (e.g. Gillies et al., (1996) have observed $755 \mu \mathrm{g} / \mathrm{m}^{3}$ suspended, background dust concentration in Sevaré, Mali). Still, during severe dust storms the concentration of the particles can exceed $10^{4}-10^{5} \mathrm{\mu g} / \mathrm{m}^{3}$ (Pye, 1987). Ganor \& Foner (2001) have measured $23,000 \mu \mathrm{g} / \mathrm{m}^{3}$ dust concentration in the Negev, while Gillies et al., 1996 have reported more than 13,000 $\mu \mathrm{g} / \mathrm{m}^{3}$ in the Sahara. However, the concentrations of dust, even during intensive dust outbreaks, rarely reach the $1000 \mu \mathrm{g} / \mathrm{m}^{3}$ value at the Canary Islands (Querol et al., 2004) or at Cape Verde (Jaenicke \& Schütz, 1978). The highest 'total dust concentration' ever recorded in Australia was measured at the Birdsville station with a value of $29,000 \mu \mathrm{g} / \mathrm{m}^{3} / \mathrm{y}$ (McTainsh et al., 2009). (The total dust concentration was defined as the sum of the daily dust concentration values.) But the magnitude and frequency of Pleistocene dust storms is unknown, conclusions can be made only on the magnitude of continuous background dust load.

As the visibility is strongly dependent on dust concentration (e.g. Chepil \& Woodruff, 1957), we are allowed to compute Late Pleistocene visibility from our calculated dust concentration data. Below are some of the empirical relationships derived by fitting dust concentration measurements to visibility, and the opposite way:

Chepil \& Woodruff (1957): $\quad C=\frac{7078}{V_{\text {is }}^{1.25}} \rightarrow V_{\text {is }}=\frac{7078}{C^{0.8}}$

Patterson \& Gillette (1977): $C=\frac{10507}{V_{\text {is }}^{1.07}} \rightarrow V_{\text {is }}=\frac{10507}{C^{0.935}}$ (Eq. 8-2)

Tews (1996)

$$
\mathrm{C}=\frac{2032}{\mathrm{~V}_{\mathrm{is}}{ }^{0.877}} \rightarrow \mathrm{V}_{\mathrm{is}}=\frac{2032}{\mathrm{C}^{1.14}}
$$

Shao et al. (2003):

$$
\left\{\begin{array}{l}
\mathrm{V}_{\text {is }}<3.5 \mathrm{~km}: \mathrm{C}=\frac{3802.29}{\mathrm{~V}_{\text {is }}^{0.84}} \rightarrow \mathrm{V}_{\text {is }}=\frac{3802.29}{\mathrm{C}^{1.19}} \\
\mathrm{~V}_{\text {is }} \geq 3.5 \mathrm{~km}: \mathrm{C}=\mathrm{e}^{\left(-0.11 \times \mathrm{V}_{\mathrm{is}}+7.62\right)} \rightarrow \mathrm{V}_{\text {is }}=\frac{\ln \left(\frac{\mathrm{C}}{\mathrm{e}^{7.62}}\right)}{-0.11}
\end{array}\right\}
$$

where $C$ is the dust concentration $\left(\mu \mathrm{g} / \mathrm{m}^{3}\right)$ and Vis is the visibility in kilometres. According to Shao (2008), the differences of (Eq. 8.1-8.4) were caused by (1) small data sets; (2) effects of
Fig.7. Sedimentary populations of the decomposed bimodal grain-size distribution curve.

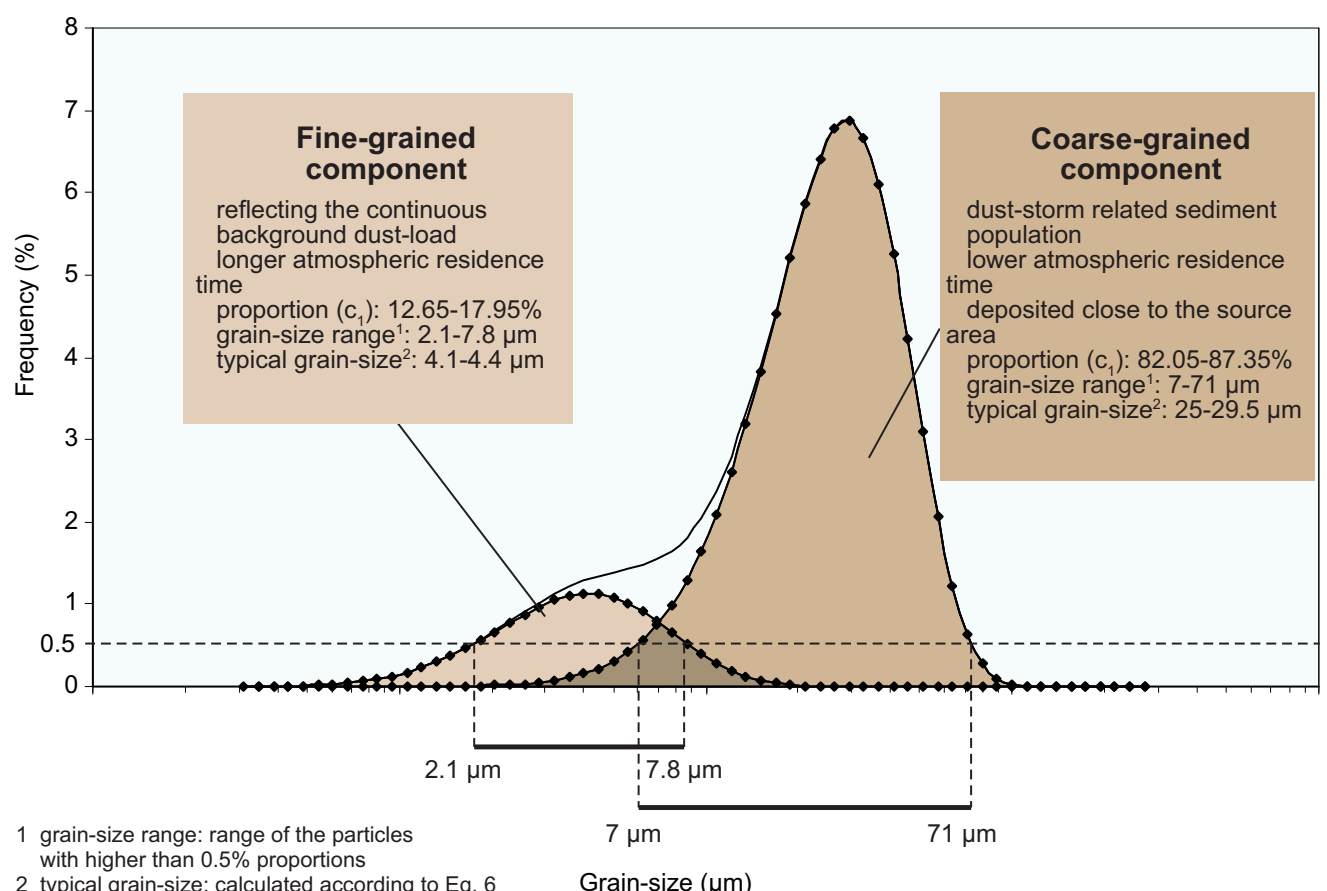

Grain-size $(\mu \mathrm{m})$ 
Table 2. Average Late Pleistocene sedimentation rates, dust flux and dust concentration values in the Carpathian Basin (source of the SR and DF values for the bulk samples: Újvári et al., 2008).

\begin{tabular}{|c|c|c|c|c|c|c|}
\hline \multirow[t]{2}{*}{ Country } & \multirow[t]{2}{*}{ Site name } & \multicolumn{2}{|c|}{ Bulk sample } & \multicolumn{3}{|c|}{ Fine-grained population } \\
\hline & & SR (m/ky) & $\mathrm{DF}\left(\mathrm{g} / \mathrm{m}^{2} / \mathrm{y}\right)$ & SR (m/ky) & DF $\left(\mathrm{g} / \mathrm{m}^{2} / \mathrm{y}\right)$ & $C\left(\mu \mathrm{g} / \mathrm{m}^{3}\right)$ \\
\hline \multirow[t]{21}{*}{ Hungary } & Albertirsa & 0,39 & 587 & $0.05-0.07$ & $74.3-105.4$ & $1489-2113$ \\
\hline & Basaharc & 0.23 & 348 & $0.03-0.04$ & $44-62.5$ & $878-1246$ \\
\hline & Bodrogkeresztúr I & 0.25 & 381 & $0.03-0.04$ & $48.2-68.4$ & $955-1355$ \\
\hline & Csorgókút I & 0.19 & 284 & $0.02-0.03$ & $35.9-51$ & $726-1030$ \\
\hline & Csorgókút II & 0.3 & 453 & $0.04-0.05$ & $57.3-81.3$ & $1146-1626$ \\
\hline & Debrecen (Alföldi brickyard) & 0.16 & 237 & $0.02-0.03$ & $30-42.5$ & $611-867$ \\
\hline & Dunaszekcső & 0.47 & 707 & $0.06-0.08$ & $89.4-126.9$ & $1795-2547$ \\
\hline & Dunaújváros & 0.83 & 1238 & $0.1-0.15$ & $156.6-222.2$ & $3170-4498$ \\
\hline & Katymár & 0.42 & 632 & $0.05-0.08$ & $79.9-113.4$ & $1604-2276$ \\
\hline & Lakitelek I & 0.17 & 254 & $0.02-0.03$ & $32.1-45.6$ & 649-921 \\
\hline & Látókép & 0.14 & 212 & $0.02-0.03$ & $26.8-38.1$ & $535-759$ \\
\hline & Madaras & 0.25 & 375 & $0.03-0.04$ & $47.4-67.3$ & $955-1355$ \\
\hline & Mende & 0.51 & 761 & $0.06-0.09$ & $96.3-136.6$ & $1948-2764$ \\
\hline & Paks & 0.95 & 1422 & $0.12-0.17$ & $179.9-255.2$ & $3628-5148$ \\
\hline & Ságvár & 0.12 & 176 & $0.02-0.02$ & $22.3-31.6$ & $458-650$ \\
\hline & Süttő & 0.39 & 584 & $0.05-0.07$ & $73.9-104.8$ & $1489-2113$ \\
\hline & Szeged-Öthalom I & 0.22 & 332 & $0.03-0.04$ & $42-59.6$ & $840-1192$ \\
\hline & Tápiósüly & 0.34 & 504 & $0.04-0.06$ & $63.8-90.5$ & $1298-1842$ \\
\hline & Tokaj (Kereszt Hill) & 0.15 & 222 & $0.02-0.03$ & $28.1-39.8$ & $573-813$ \\
\hline & Tokaj (Patkó-quarry) & 0.22 & 332 & $0.03-0.04$ & 42-59.6 & $840-1192$ \\
\hline & Üveghuta-2 & 0.23 & 338 & $0.03-0.04$ & $42.8-60.7$ & $878-1246$ \\
\hline \multirow[t]{2}{*}{ Croatia } & Erdut & 0.14 & 215 & $0.02-0.03$ & $27.2-38.6$ & $535-759$ \\
\hline & Zmajevac & 0.29 & 437 & $0.04-0.05$ & $55.3-78.4$ & $1107-1571$ \\
\hline \multirow[t]{10}{*}{ Serbia } & Batajnica & 0.22 & 329 & $0.03-0.04$ & $41.6-59.1$ & 840-1192 \\
\hline & Crvenka & 0.13 & 197 & $0.02-0.02$ & $24.9-35.4$ & $496-704$ \\
\hline & Irig & 0.13 & 192 & $0.02-0.02$ & $24.3-34.5$ & 496-704 \\
\hline & Mošorin & 0.26 & 395 & $0.03-0.05$ & $50-70.9$ & $993-1409$ \\
\hline & Petrovaradin & 0.12 & 174 & $0.02-0.02$ & $22-31.2$ & $458-650$ \\
\hline & Ruma & 0.13 & 192 & $0.02-0.02$ & $24.3-34.5$ & 496-704 \\
\hline & Stari Slankamen & 0.11 & 168 & $0.01-0.02$ & $21.3-30.2$ & $420-596$ \\
\hline & Surduk & 0.29 & 434 & $0.04-0.05$ & $54.9-77.9$ & $1107-1571$ \\
\hline & Susek & 0.1 & 150 & $0.01-0.02$ & $19-26.9$ & $382-542$ \\
\hline & Titel & 0.34 & 510 & $0.04-0.06$ & $64.5-91.5$ & $1298-1842$ \\
\hline
\end{tabular}

grain size and humidity; and (3) subjectivity. However, it could be interesting to know more about the visibility relations of the Late Pleistocene, also in regard to other disciplines. From the viewpoint of archaeology, the limited view distance made the orientation, hunting and communication of the prehistoric societies more difficult.

The results of (Eq. 8-3) and (Eq. 8-4) provided too low visibility values $(<5 \mathrm{~km})$ even at relatively low dust concentration $\left(<200 \mu \mathrm{g} / \mathrm{m}^{3}\right)$. So, the Chepil-Woodruff and the Patterson-Gillette formulas were used in our calculations. However these results have shown some differences as well, therefore their combined minimum and maximum were chosen as limits of average visibility (Fig. 8).
Based on the above-mentioned relationships, the average Late Pleistocene visibility can be set in the range between 6.5 to 26 kilometres. According to the World Meteorological Organisation's protocol, these values can be classified into dust-in-suspension and blowing dust categories. However, these values are averages and related only to the background dust load. During severe Late Pleistocene dust storms the visibility could certainly drop to almost zero. 
Fig.8. Relationship between the dust concentration and the visibility by Chepil \& Woodruff, (1957) and Patterson \& Gillette, (1977), and the estimated range of the Pleistocene dust concentration.

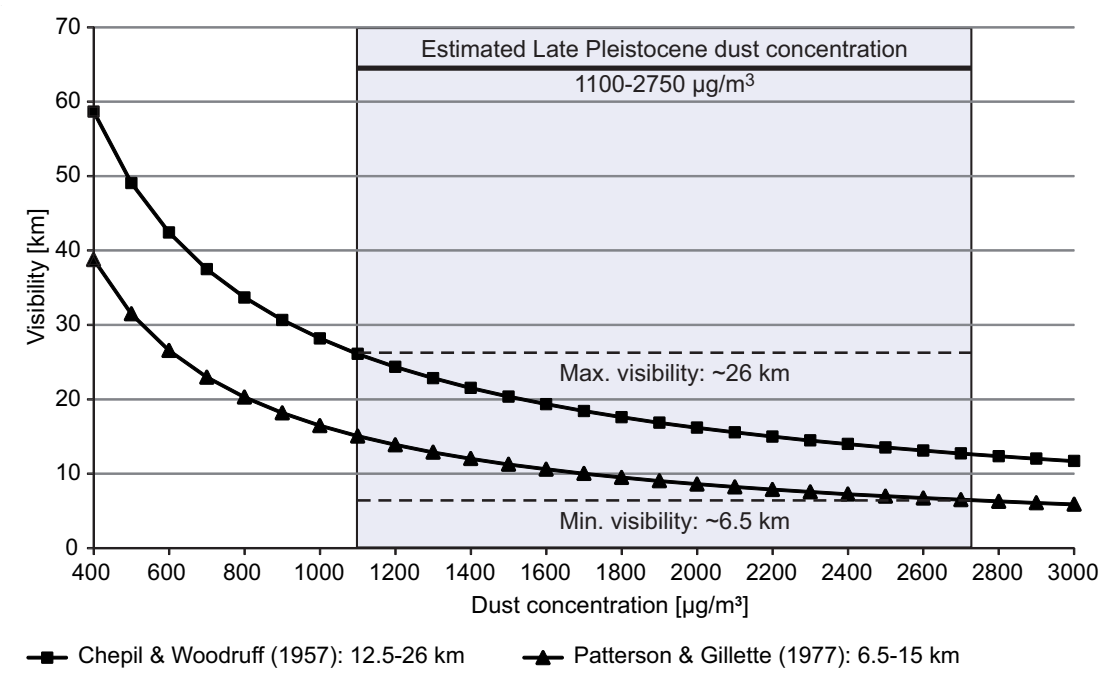

\section{Acknowledgements}

The authors appreciate the efforts of the two anonymous reviewers and their useful comments and suggestions for improving the manuscript. This contribution was made possible through financial support for J. Kovács and G. Ujvári by the Hungarian Academy of Sciences, Bolyai János Research Grant and Developing Competitiveness of Universities in the South Transdanubian Region (SROP-4.2.1.B-10/2/KONV-2010-0002), and Austrian Agency for International Education \& Research, financed by the Scholarship Foundation of the Republic of Austria.

\section{References}

Antoine, P., Rousseau, D.D., Fuchs, M., Hatté, C., Gauthier, C., Marković, S.B., Jovanović, M., Gaudenyi, T., Moine, 0. \& Rossignol, J., 2009. High-resolution record of the last climatic cycle in the southern Carpathian Basin (Surduk, Vojvodina, Serbia). Quaternary International 198: 19-36.

Bokhorst, M.P., Beets, C.J., Markovic, S.B., Gerasimenko, N.P., Matviishina, Z.N. \& Frechen, M., 2009. Pedo-chemical climate proxies in Late Pleistocene Serbian-Ukranian loess sequences. Quaternary International 198: 113-123.

Bokhorst, M.P., Vandenberghe, J., Sümegi, P., Lanczont, M., Gerasimenko, N.P., Matviishina, Z.N., Markovic, S.B. \& Frechen, M., 2011. Atmospheric circulation patterns in central and eastern Europe during the Weichselian Pleniglacial inferred from loess grain-size records. Quaternary International 234: 62-74.

Buggle, B., Glaser, B., Zöller, L., Hambach, U., Markovic, S., Glaser, I. \& Gerasimenko, N., 2008. Geochemical characterisation and origin of southeastern and eastern European loesses. Quaternary Science Reviews 27: 10581075.

Buggle, B., Hambach, U., Glaser, B., Gerasimenko, N., Marković, S.B., Glaser, I. \& Zöller, L., 2009. Stratigraphy, and spatial and temporal paleoclimatic trends in Southeastern/Eastern European loess-paleosol sequences. Quaternary International 196: 86-106.

Chepil, W.S. \& Woodruff, N.P., 1957. Sedimentary characteristics of dust storms - visibility and dust concentration. American Journal of Science 255: 104-114. 
Dobosi, V., 1967. Új felső-paleolit telep az Alföldön. (New Upper Paleolithic settlement on the Great Hungarian Plain). Archeológiai Értesítő 94: 184-193.

EPICA community members, 2004. Eight glacial cycles from an Antarctic ice core. Nature 429: 623-628.

Frechen, M., Horvath, E. \& Gabris, G., 1997. Geochronology of middle and upper Pleistocene loess sections in Hungary. Quaternary Research 48: 291-312.

Gábori-Csánk, V., 1960. A ságvári telep abszolút kormeghatározása. (Absolute age determination of the settlement at Ságvár). Archeológiai Értesítő 87: 125-129.

Gábris, Gy., 2007. The relation between the time scale of the Quaternary surface processes and oxygen isotope stratigraphy according to the loess-palaeosoil sequences and river terraces in Hungary. Földtani Közlöny 137: 515-540.

Galović, L., Frechen, M., Halamić, J., Durn, G. \& Romić, M., 2009. Loess chronostratigraphy in Eastern Croatia - A luminescence dating approach. Quaternary International 198: 85-97.

Ganor, E. \& Foner, H.A., 2001. Mineral dust concentrations, deposition fluxes and deposition velocities in dust episodes over Israel. Journal of Geophysical Research. Atmospheres 106 (D16): 18431-18438.

Geyh, M.A., Schweitzer, F., Vértes, L. \& Vogel, I.C., 1969. A magyarorszagi würmi eljegesedés új kronológiai adatai. (New chronological data of the Weichselian glaciation in Hungary). Földrajzi Közlemények 18: 5-18.

Gillies, J.A., Nickling, W.G. \& McTainsh, G.H., 1996. Dust concentration and particle-size characteristics of an intense dust haze event: Inland Delta Region, Mali, West Africa. Atmospheric Environment 30: 1081-1090.

Harrison, S.P., Kohfeld, K.E., Roelandt, C. \& Claquin, T., 2001. The role of dust in climate changes today, at the last glacial maximum and in the future. Earth-Science Reviews 54: 43-80.

Hupuczi, J., Lócskai, T., Hum, L. \& Sümegi, P., 2006. Heinrich események kimutatása hazai löszszelvény alapján. (The demonstration of Heinrich events in Hungarian loess profiles). Malakológiai Tájékoztató 24: 31-34.

Hupuczi, J. \& Sümegi, P., 2010. The Late Pleistocene paleoenvironment and paleoclimate of the Madaras section (south Hungary), based on preliminary records from mollusks. Central European Journal of Geosciences 2: 64-70.

Jaenicke, R. \& Schütz, L., 1978. Comprehensive study of physical and chemical properties of the surface aerosols in the Cape Verde Islands regions. Journal of Geophysical Research. 0ceans and atmospheres 83: 3585-3599.

Jickells, T.D., An Z., Andersen, K.K., Baker, A.R., Bergametti, G., Brooks, N., Cao Junji, Boyd, P.W., Duce, R.A., Hunter, K.A., Kawahata, H., Kubilay, N., laRoche, J., Liss, P.S., Mahowald, N., Prospero, J.M., Ridgwell, A.J., Tegen, I. \& Torres, R., 2005. Global iron connections between desert dust, ocean biogeochemistry, and climate. Science 308: 67-71.

Kohfeld, K.E. \& Tegen, I., 2007. Record of mineral aerosols and their role in the earth system. Treatise on Geochemistry 4: 1-26.

Konert, M. \& Vandenberghe, J., 1997. Comparison of laser grain-size analysis with pipette and sieve analysis: a solution for the underestimation of the clay fraction. Sedimentology 44: 523-535.

Koloszár, L. \& Marsi, I., 2005. Formations of Late Neogene and Pleistocene terrestrial sediments in the region of Mórágy Hill (Hungary). Acta Geologica Hungarica 48: 317-337.

Kovács, J., 2008. Grain-size analysis of the Neogene red clay formation in the Pannonian Basin. International Journal of Earth Sciences 97: 171-178.
Kovács, J., Varga, Gy. \& Dezsö, J., 2008. Comparative study on the Late Cenozoic red clay deposits from China and Central Europe (Hungary). Geological Quarterly 52: 369-382.

Krolopp, E. \& Sümegi, P., 2002. A ságvári lösz-rétegsor csigafaunája. (The mollusc fauna of the Ságvár loess profile). Malakológiai Tájékoztató 20: 7-14.

Krolopp, E., Sümegi, P., Kuti, L., Hertelendi, E. \& Kordos, L., 1996. Szeged környéki löszképződmények keletkezésének paleoökológiai rekonstrukciója. (Palaeoecological reconstruction of the formation of loess deposits in the environs of Szeged). Földtani Közlöny 125: 309-361.

Lisiecki, L. \& Raymo, M.E., 2005. A Pliocene-Pleistocene stack of 57 globally distributed benthic 180 records. Paleoceanography 20: PA1003, 17 p.

Lócskai, T., Hupuczi, J., Hum, L. \& Sümegi, P., 2006. Dansgaard-Oeschger ciklusok kimutatása hazai löszszelvényből. (The demonstration of Dansgaard-0eshger cycles from Hungarian loess profiles). Malakológiai Tájékoztató 24: 35-39.

Lun, I.Y.F. \& Lam, J.C., 2000. A study of Weibull parameters using long-term wind observations. Renewable Energy 20: 145-153.

Mahowald, N. M., Muhs, D.R., Levis, S., Rasch, P.J., Yoshioka, M., Zender, C.S. \& Luo, C., 2006. Change in atmospheric mineral aerosols in response to climate: Last glacial period, preindustrial, modern, and doubled carbon dioxide climates. Journal of Geophysical Research 111, D10202, 22 p.

Markovic, S.B., Kostic, N. \& Oches, E.A., 2004. Paleosols in the Ruma loess section. Revista Mexicana de Ciencias Geológicas 21: 79-87.

Markovic, S.B., McCoy, W.D., Oches, E.A., Savic, S., Gaudenyi, T., Jovanovic, M., Stevens, T., Walther, R., Ivanisevic, P. \& Galic, Z., 2005. Paleoclimate record in the upper Pleistocene loess-palaeosol sequence at Petrovaradin brickyard (Vojvodina, Serbia). Geologica Carpathica 56: 545-552.

Markovic, S.B., Oches, E.A., Sümegi, P., Jovanovic, M. \& Gaudenyi, T., 2006. An introduction to the middle and upper Pleistocene loess-palaeosol sequence at Ruma brickyard, Vojvodina, Serbia. Quaternary International 149: 80-86.

Markovic, S.B., Oches, E.A., McCoy, W.D., Frechen, M. \& Gaudenyi, T., 2007. Malacological and sedimentological evidence for 'warm' glacial climate from the Irig loess sequence, Vojvodina, Serbia. Geochemistry Geophysics Geosystems 8: 009008. 12 p.

Markovic, S.B., Bokhorst, M.P., Vandenberghe, J., McCoy, W.D., Oches, E.A., Hambach, U., Gaudenyi, T., Jovanovic, M., Stevens, T., Zöller, L. \& Machalett, B., 2008. Late Pleistocene loess-palaeosol sequences in the Vojvodina region, North Serbia. Journal of Quaternary Science 23: 73-84.

Markovic, S.B., Hambach, U., Catto, N., Jovanovic, M., Buggle, B., Machalett, B., Zöller, L., Glaser, B. \& Frechen, M., 2009. The middle and late Pleistocene loess-palaeosol sequences at Batajanica, Vojvodina, Serbia. Quaternary International 198: 255-266.

Marsi, I., Don, Gy., Földvári, M., Koloszár, L., Kovács-Pálffy, P., Krolopp, E., Lantos, M., Nagy-Bodor, E. \& Zilahi-Sebess, L., 2004. Quaternary sediments of the northeastern Mórágy Block. Annual Report of the Geological Institute of Hungary for the Year 2003: 343-359.

McTainsh, G.H. \& Pitblado, J.R., 1987. Dust storms and related phenomena measured from meteorological records in Australia. Earth Surface Processes and Landforms 12: 415-424.

McTainsh, G.H., Nickling, W.G. \& Lynch, A.W., 1997. Dust deposition and particle size in Mali, West Africa. Catena 29: 307-322.

McTainsh, G.H., Strong, C. \& Leys, J., 2009. Wind erosion histories, model input data and community DustWatch. Atmospheric Environment Research Centre, Griffith University, Brisbane, $221 \mathrm{p}$. 
Novothny, Á., Horváth, E. \& Frechen, M., 2002. The loess profile at Albertirsa, Hungary - improvements in loess stratigraphy by luminescence dating. Quaternary International 95/96: 155-163.

Novothny, Á., Frechen, M., Horváth, E., Bradák, B., Oches, E.A., McCoy, W.D. \& Stevens, T., 2009. Luminescence and amino acid racemisation chronology of the loess-paleosol sequence at Süttő, Hungary. Quaternary International 198: $62-76$.

Oches, E.A. \& McCoy, W.D., 1995. Aminostratigraphic evaluation of conflicting age estimates for the 'Young Loess' of Hungary. Quaternary Research 44: 160-170.

Patterson, E.M. \& Gillette, D.A., 1977. Measurements of visibility vs. mass concentration for airborne soil particles. Atmospheric Environments 10: 83-96.

Peticzka, R., Holawe, F. \& Riegler, D., 2010. Structural analyses on the modified paleosol-sequence of 'Stillfried $B^{\prime}$ with high resolution measurements of selected laboratory parameters. Quaternary International 222: 168-177.

Pécsi, M., 1968. Loess. In: Fairbridge, R.W. (ed.): The Encyclopaedia of Geomorphology, Reinhold, New York: 674-678.

Pécsi, M., 1979. Lithostratigraphical subdivision of the loess profiles at Paks. Acta Geologica Hungarica 22: 409-418.

Pécsi, M., 1985. Chronostratigraphy of Hungarian loesses and underlying subaerial formation. In: Pécsi, M. (ed.): Loess and the Quaternary: Chinese and Hungarian Case Studies. Studies in Geography in Hungary 18: 33-49.

Pécsi, M., 1990. Loess is not just the accumulation of dust. Quaternary International 7-8: 1-21.

Pécsi, M. \& Pevzner, M.A., 1974. Paleomagnetic measurements in the loess sequences at Paks and Dunaföldvár, Hungary. Földrajzi Közlemények 22: 215-224.

Pécsi, M. \& Schweitzer, F., 1995. The lithostratigraphical, chronostratigraphical sequence of Hungarian loess profiles and their geomorphological position. In: Pécsi, M. \& Schweitzer, F. (eds): Loess InForm 3. Concept of loess, loesspaleosol stratigraphy. MTA FKI, Budapest: 31-61.

Pósfai, M. \& Buseck, P.R., 2010. Nature and climate effects of individual tropospheric aerosol particles. Annual Review of Earth and Planetary Sciences 38: 17-43.

Prins, M.A. \& Vriend, M., 2007. Glacial and interglacial eolian dust dispersal patterns across the Chinese Loess Plateau inferred from decomposed loess grain-size records. Geochemistry, Geophysics, Geosystems 8: 007005, 17 p.

Prins, M.A., Vriend, M., Nugteren, G., Vandenberghe, J., Lu, H., Zheng, H. \& Weltje, G.J., 2007. Late Quaternary aeolian dust flux variability on the Chinese Loess Plateau: Inferences from unmixing of loess grain-size records. Quaternary Science Reviews 26: 230-242.

Pye, K., 1987. Aeolian Dust and Dust Deposits. Academic Press, London: 334 p.

Pye, K., 1995. The nature, origin and accumulation of loess. Quaternary Science Reviews 14: 653-667.

Querol, X., Alastuey, A., Rodríguez, S., Viana, M.M., Artínano, B., Salvador, P., Mantilla, E., García do Santos, S., Fernandez Patier, R., de La Rosa, J., Sanchez de la Campa, A., Menéndez, M. \& Gil, J.J., 2004. Levels of particulate matter in rural, urban and industrial sites in Spain. Science of the Total Environment 334-335: 359-376.

Ridgwell, A.J., 2002. Dust in the Earth system: the biogeochemical linking of land, air and sea. Philosophical Transactions of the Royal Society A. 360: 2905-2924.
Rosenfeld, D., Rudich, Y. \& Lahav, R., 2001. Desert dust suppressing precipitation: A possible desertification feedback loop. The Proceedings of the National Academy of Sciences of the United States of America 98: 5975-5980.

Sassen, K., DeMott, P.J., Prospero, J.M. \& Poellot, M.R., 2003. Saharan dust storms and indirect aerosol effects on clouds: CRYSTALFACE results. Geophysical Research Letters 30: 1633, 4 p.

Schmidt, E.D., Machalett, B., Marković, S.B., Tsukamoto, S. \& Frechen, M., 2009. Luminescence chronology of the upper part of the Stari Slankamen loess sequence (Vojvodina, Serbia). Quaternary Geochronology: 1-6.

Seppäla, M., 1971. Stratigraphy and material of the loess layers at Mende, Hungary. Bulletin of the Geological Society of Finland 43: 109-123.

Shao, Y., 2008. Physics and Modelling of Wind Erosion. ( $2^{\text {nd }}$ Revised and Expanded Edition) Springer, $452 \mathrm{pp}$.

Shao, Y., Yang, Y., Wang, J.J., Song, Z. X., Leslie, L.M., Dong, C.H., Zhang, Z.H., Lin, Z.H., Kanai, Y., Yabuki, S. \& Chun, Y.S., 2003. Real-time numerical prediction of northeast Asian dust storms using an integrated modeling system. Journal of Geophysical Research 108: 4691, 18 p.

Sun, D., Bloemendal, J., Rea, D.K., Vandenberghe, J., Jiang, F., An, Z. \& Su, R., 2002. Grain-size distribution function of polymodal sediments in hydraulic and aeolian environments, and numerical partitioning of the sedimentary components. Sedimentary Geology 152: 263-277.

Sun, D., Bloemendal, J., Rea, D.K., An, Z., Vandenberghe, J., Lu, H., Su, R. \& Liu, T.S., 2004. Bimodal grain-size distribution of Chinese loess, and its paleoclimatic implications. Catena 55: 325-340.

Sümegi, P., 2005. Loess and Upper Paleolithic Environment in Hungary. Aurea Kiadó, Nagykovácsi: 312 pp.

Sümegi, P. \& Hertelendi, E., 1998. Reconstruction of microenvironmental changes in Kopasz Hill loess area at Tokaj (Hungary) between 15,000-70,000 BP years. Radiocarbon 40: 855-863.

Sümegi, P., Molnár, M., Svingor, E.., Szántó, Zs, Hum, L. \& Gulyás, S., 2007. Results of radiocarbon analysis of Upper Weichselian loess sequences from Hungary. Radiocarbon 49: 1023-1030.

Stevens, T., Markovic, S.B., Zech, M., Hambach, U. \& Sümegi, P., 2011. Dust deposition and climate in the Carpathian Basin over an independently dated last glacial-interglacial cycle. Quaternary Science Reviews 30: 662-681.

Stuut, J-B., Smalley, I. \& O'Hara-Dhand, K., 2009. Aeolian dust in Europe: African sources and European deposits. Quaternary International 198: 234-245.

Tegen, I., Lacis, A. A. \& Fung, I., 1996. The influence of mineral aerosols from disturbed soils on climate forcing. Nature 380: 419-422.

Tews, E.K., 1996. Wind erosion rates from meteorological records in eastern Australia 1960-92. B.Sc. thesis, Griffith University

Újvári, G., Varga, A. \& Balogh-Brunstad, Z., 2008. Origin, weathering, and geochemical composition of loess in southwestern Hungary. Quaternary Research 69: 421-437.

Újvári, G., Kovács, J., Varga, Gy., Raucsik, B. \& Marković, S.B., 2010. Dust flux estimates for the Last Glacial Period in East Central Europe based on terrestrial records of loess deposits: a review. Quaternary Science Reviews 29: 3157-3166.

Varga, Gy., 2011. Similarities among the Plio-Pleistocene terrestrial aeolian dust deposits in the world and in Hungary. Quaternary International 234: 98-108.

Vogel, I.C. \& Waterbolk, H.T., 1964. Groningen radiocarbon dates. V. Radiocarbon 6: 349-369. 
Vriend, M. \& Prins, M.A., 2005. Calibration of modelled mixing patterns in loess grain-size distributions: an example from the north-eastern margin of the Tibetan Plateau, China. Sedimentology 52: 1361-1374.

Weltje, G.J., 1997. End-member modeling of compositional data: numericalstatistical algorithms for solving the explicit mixing problem. Journal of Mathematical Geology 29: 503-549.

Weltje, G.J. \& Prins, M.A., 2003. Muddled or mixed? Inferring palaeoclimate from size distributions of deep-sea clastics. Sedimentary Geology 162: 39-62.

Weltje, G.J. \& Prins, M.A., 2007. Genetically meaningful decomposition of grainsize distributions. Sedimentary Geology 202: 409-424.

Willis, K.J., Rudner, Z.E. \& Sümegi, P., 2000. Full-glacial forests of central and southeastern Europe. Quaternary Research 53: 203-213.

Wintle, A.G. \& Packman, S.C., 1988. Thermoluminescence ages for three sections in Hungary. Quaternary Science Reviews 7: 315-320.

Zender, C.S., Bian, H.S. \& Newman, D., 2003. Mineral Dust Entrainment and Deposition (DEAD) model: Description and 1990s dust climatology. Journal of Geophysical Research - Atmospheres 108: 4416, 19 p.

Zöller, L., Oches, E.A. \& McCoy, W.D., 1994. Towards a revised chronostratigraphy of loess in Austria with respect to key sections in the Czech Republic and in Hungary. Quaternary Geochronology / Quaternary Science Reviews 13: 465-472.

Zöller, L. \& Wagner, G.A., 1990. Thermoluminescence dating of loess - recent developments. Quaternary International 7/8: 119-128. 